\title{
Further experiments on the nutrition of sledge dogs
}

\author{
By H. T. WYATT \\ Division of Human Physiology, National Institute for Medical Research, \\ Medical Research Council, Hampstead, London, N.W. 3
}

\section{(Received 9 August 1961-Revised 25 April 1963)}

Sledge dogs are still widely used as draught animals on polar expeditions despite the increasing use of mechanical transport. They live and thrive whilst kept continuously out of doors in all but the most extreme conditions. At the bases they are fed on a diet of seal or other raw meat, but during sledging journeys, when fresh meat may not be available, all dog food must be carried on the sledges or previously laid ahead of the parties in depots. For many years the standard British ration was $454 \mathrm{~g}(\mathrm{I} \mathrm{lb}) /$ day of pemmican, a dehydrated concentrated food developed by Watkins (1932) for the British Arctic Air Route Expedition, but this diet has been considered unsatisfactory both in quantity and in quality (Bingham, I94I).

Experiments on the nutrition of sledge dogs were conducted both in Britain and in Antarctica (Taylor, Worden \& Waterhouse, 1959) and an assessment was made of dog pemmican, which consisted of approximately two-thirds protein and one-third fat. The ration of $\mathrm{I} \mathrm{lb} /$ day was not sufficient to maintain the weight of tethered dogs, and a thiamine deficiency was demonstrated. Diarrhoea was usual, and faecal nitrogen excretion was $30 \%$ of the amount ingested. Taylor et al. (1959) developed a new diet for dogs containing approximately $30 \%$ protein, $40 \%$ fat and 10 $\%$ carbohydrate, to which were added $\mathrm{I} \cdot 2 \mathrm{mg}$ thiamine, Io $\mathrm{mg}$ nicotinic acid, $3 \mathrm{mg}$ riboflavin, rooo i.u. vitamin $\mathrm{A}, 600$ i.u. vitamin $\mathrm{D}, 20 \mathrm{mg}$ calcium pantothenate and $0.4 \mathrm{mg}$ pyridoxine for each I lb block.

Feeding trials were conducted in Antarctica in 1957 and 1958 , when the old diet $(\operatorname{diet} A)$ was compared with the new $\operatorname{diet}(\operatorname{diet} B)$ and with a further slight modification of the new diet (diet $\mathrm{C}$ ). The results of the experiments are reported in this paper.

\section{METHODS}

Thirty-two male husky dogs were used at bases W (lat. $66^{\circ} 52^{\prime} \mathrm{S}$, long. $66^{\circ} 4^{\prime} 8^{\prime} \mathrm{W}$ ) and $\mathrm{E}$ (lat. $68^{\circ} \mathrm{II}^{\prime} \mathrm{S}$, long. $67^{\circ} 00^{\prime} \mathrm{W}$ ) of the British Antarctic Survey, formerly the Falkland Islands Dependencies Survey. Sixteen were less than 2 years old, twelve between 2 and 6 years old, and four older than 6 years; most had sledged considerable distances before the tests and had been accustomed to concentrated diets while travelling. Before each trial they were fed on seal meat for at least 2 weeks.

Diets A and B were compared in two trials with dogs tethered on snow near the base hut, and in two trials with dogs pulling a loaded sledge in the daytime and tethered separately at night. A third trial with tethered dogs was performed at the base to compare diets $\mathrm{A}, \mathrm{B}$ and $\mathrm{C}$. 
Groups of dogs were selected and matched by weight and if possible by age. Each group was given daily $\mathrm{I} \mathrm{lb} / \mathrm{dog}$ of a different diet for periods of up to $3^{\mathrm{I}}$ days and body-weight changes and faecal excretions of $\mathrm{N}$ and fat were measured. In the experiments on tethered dogs the diet given to each group was changed at the midpoint, so that a cross-over experiment was performed; in the trials using working dogs there was no cross-over. Details of the five trials are given in Table $\mathrm{I}$.

Table I. Details of the five feeding trials with sledge dogs

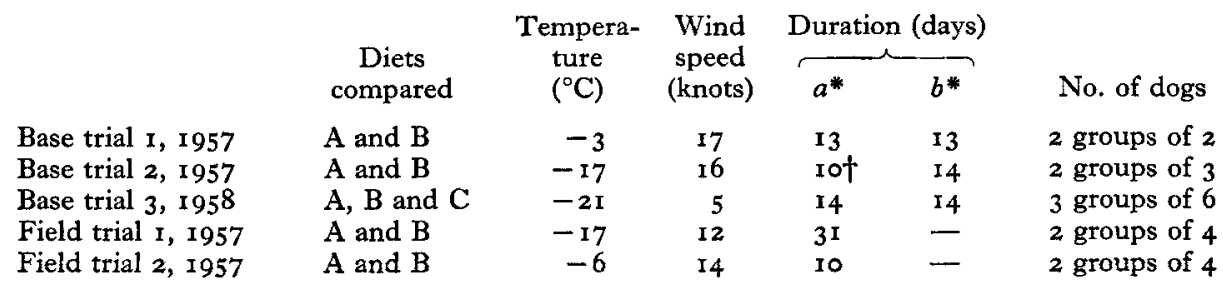

* $a$ before, and $b$ after, change-over of diets.

$\uparrow$ This period was reduced to ro days because two dogs escaped and ate seal meat between the Ioth and $14^{\text {th }}$ days.

Table 2. Composition of diets $A, B$ and $C$ and of seal meat

\begin{tabular}{|c|c|c|c|c|c|}
\hline & Diet A & Diet B & Diet C & $\begin{array}{l}\text { Seal meat } \\
\text { with blubber } \\
\text { and skin }\end{array}$ & $\begin{array}{c}\text { Seal meat, } \\
\text { lean }\end{array}$ \\
\hline & \multicolumn{5}{|c|}{ Composition (g/100 g) } \\
\hline Moisture & $8 \cdot 7$ & $8 \cdot 6$ & $8 \cdot 1$ & $44^{\circ} 9$ & $71 \cdot 5$ \\
\hline Protein $(\mathrm{N} \times 6.25)$ & $62 \cdot 3$ & $29 \cdot 5$ & 29.9 & 18.0 & 26.6 \\
\hline & $28 \cdot 2$ & $41 \cdot 6$ & $38 \cdot I$ & $38 \cdot 7$ & 0.4 \\
\hline Carbohydrate & - & ino & $17 \cdot 8$ & - & - \\
\hline \multirow[t]{2}{*}{ Ash } & $1 \cdot 7$ & $7 \cdot I$ & 5.6 & 0.7 & $I \cdot 2$ \\
\hline & \multicolumn{5}{|c|}{ Mineral content (mg/100 g) } \\
\hline Sodium & 326 & 497 & 495 & 90 & 46 \\
\hline Potassium & 123 & 616 & 565 & 187 & 473 \\
\hline Calcium & 76 & I559 & II 33 & 7 & 4 \\
\hline Magnesium & 33 & 86 & 75 & 14 & 26 \\
\hline Iron & 33 & 6 & 7 & 9 & - \\
\hline Chloride & 425 & 587 & 592 & 83 & 44 \\
\hline \multirow[t]{5}{*}{ Phosphorus } & 275 & 1065 & 843 & 99 & 220 \\
\hline & \multicolumn{5}{|c|}{ Thiamine content $(\mathrm{mg} / \mathrm{ro0} \mathrm{g})$} \\
\hline & 0.04 & 0.20 & 0.68 & - & 0.13 \\
\hline & \multicolumn{5}{|c|}{ Calorie equivalent (kcal/soo g) } \\
\hline & 517 & $55^{2}$ & 550 & 433 & 112 \\
\hline
\end{tabular}

A spring balance graduated in $\mathrm{lb}$ and reading to $200 \mathrm{lb}(9 \mathrm{I} \mathrm{kg}$ ) was used for measurement of body-weight. Oscillations of the scale pointer were sometimes violent when the balance was suspended from a tripod out of doors. Errors were assessed by making ten weighings of one dog within a $\frac{1}{2} \mathrm{~h}$ period; it was concluded that the weight could be measured to within $\pm \mathrm{I} \mathrm{lb}$.

On four to six occasions during each trial faeces were collected for $24 \mathrm{~h}$. Errors 
arising from over- or under-collection of representative $24 \mathrm{~h}$ samples, due to irregular defaecation by the dogs and to their almost invariable coprophagy, were minimized by regular hourly inspection of the dog spans. Samples of about $50 \mathrm{~g}$ were dried over a boiling water-bath for $\mathrm{to} \mathrm{h}$, with small additions of absolute alcohol to assist drying. The dried samples were sealed in corked glass tubes and sent to Cambridge where they were further dried to constant weight and analysed for $\mathrm{N}$ by the micro-Kjeldahl method with copper selenite as catalyst, and for fat by the method described by King (I946).

The compositions of the three experimental diets and specimens of lean seal meat, and seal meat including blubber and skin, are shown in Table 2. The methods used for the analysis of these foods were in general those described by McCance \& Shipp (1933) and McCance, Widdowson \& Shackleton (1936). The starch in diets B and C was hydrolysed with Takadiastase (Parke, Davis \& Co.) and the glucose determined by the Munsen-Walker method (Association of Official Agricultural Chemists, 1950). Sodium and potassium were determined in an EEL flame photometer (Evans Electroselenium Ltd) after phosphate had been removed from the extract of the ash with solid $\mathrm{Ca}(\mathrm{OH})_{2}$ (Widdowson \& Southgate, 1959). Thiamine was measured by the thiochrome method of Harris \& Wang (194r).

\section{RESULTS}

Weight changes

All weight changes were adjusted to a period of ro days and the means for each trial are shown in Table 3. Weight loss appeared to be greater in the first part of each trial, before the diets given to each group were changed over, than in the second part. No effect due to the change of diet was demonstrated.

Table 3. Mean weight changes $(\mathrm{kg})$ of the sledge dogs in each trial adjusted to a period of 1o days (a) before and (b) after change-over of diets

\begin{tabular}{|c|c|c|c|c|c|c|}
\hline & \multicolumn{2}{|c|}{ Diet A } & \multicolumn{2}{|c|}{ Diet B } & \multicolumn{2}{|c|}{ Diet $\mathbf{C}$} \\
\hline & $\begin{array}{l}\text { No. of } \\
\text { dogs }\end{array}$ & $\begin{array}{l}\text { Mean } \\
\text { weight } \\
\text { change }\end{array}$ & $\begin{array}{l}\text { No. of } \\
\text { dogs }\end{array}$ & $\begin{array}{l}\text { Mean } \\
\text { weight } \\
\text { change }\end{array}$ & $\begin{array}{l}\text { No. of } \\
\text { dogs }\end{array}$ & $\begin{array}{l}\text { Mean } \\
\text { weight } \\
\text { change }\end{array}$ \\
\hline Base trial I: $\begin{array}{r}a \\
b\end{array}$ & $\begin{array}{l}2 \\
2\end{array}$ & $\begin{array}{c}-1 \cdot 4 \\
0\end{array}$ & $\begin{array}{l}2 \\
2\end{array}$ & $\begin{array}{r}-I \cdot I \\
I \cdot I\end{array}$ & - & $\overline{-}$ \\
\hline Base trial 2: $\underset{b}{a}$ & $\begin{array}{l}3 \\
3\end{array}$ & $\begin{array}{l}-1 \cdot 9 \\
-0.5\end{array}$ & $\begin{array}{l}3 \\
3\end{array}$ & $\begin{array}{l}-1.4 \\
-0.5\end{array}$ & - & - \\
\hline $\begin{array}{r}\text { Base trial } 3: a \\
b^{*}\end{array}$ & - & $\begin{array}{l}- \\
-0.7\end{array}$ & 12 & $-I \cdot 2$ & $\begin{array}{r}6 \\
10\end{array}$ & $\begin{array}{l}-1.3 \\
-0.3\end{array}$ \\
\hline Field trial $\mathrm{I}: a$ & 4 & $-3 \cdot 7$ & 4 & -3.6 & - & 一 \\
\hline Field trial 2: $a$ & 4 & $-2 \cdot 7$ & 4 & $-2 \cdot 6$ & - & - \\
\hline
\end{tabular}

* During this period three dogs escaped and ate seal meat. The weight changes of these dogs were not included in the calculations. 


\section{Composition of the faeces}

The faeces of dogs fed on diet A were noticeably different from those of dogs fed on diets $\mathrm{B}$ and $\mathrm{C}$. On diet $\mathrm{A}$ the dogs tended to defaecate three to four times daily, producing large amounts of loose, watery, dark faeces. On diets $\mathrm{B}$ and $\mathrm{C}$ they usually defaecated once or twice daily producing well-formed, light-coloured faeces.

The amounts of $\mathrm{N}$ and of fat excreted in the faeces, shown in Table 4, differed between the diets. Dogs fed on diet A excreted more $\mathrm{N}$ and less fat than did dogs fed on diet B.

Table 4. Mean values and standard deviations for excretion in the faeces and for availability of nitrogen and fat to the sledge dogs

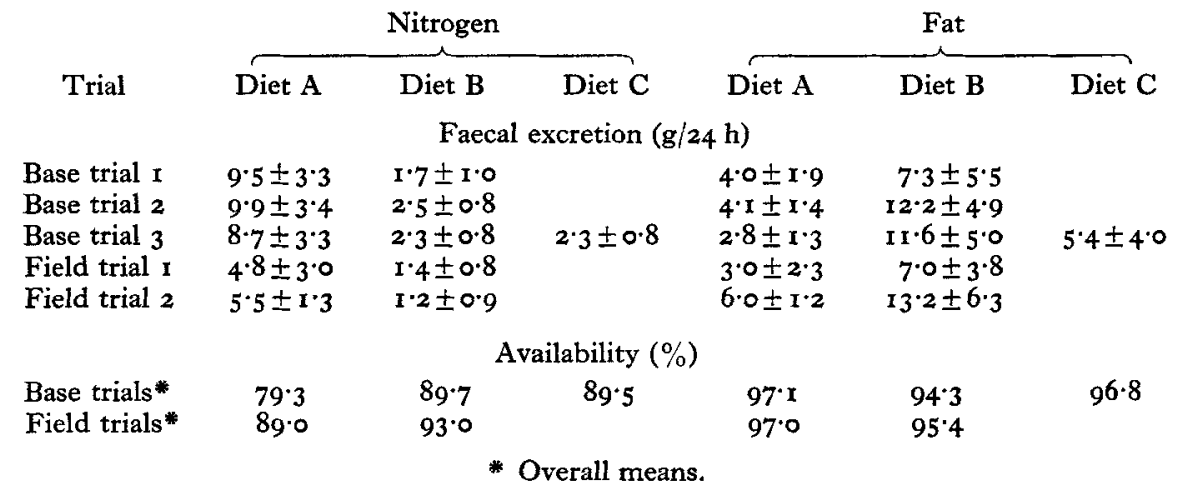

\section{Utilization of food constituents}

To compare the utilization of the food constituents in the three diets the availabilities, i.e. the net absorption as a percentage of the intake, of $\mathrm{N}$ and of fat were calculated. The overall means of availability in tethered and in working dogs are shown in Table 4. Comparisons between diets were tested on a within-dog basis.

In tethered dogs the availability of $\mathrm{N}$ was greater on diets $\mathrm{B}$ and $\mathrm{C}$ than on $\operatorname{diet} \mathrm{A}$ $(P<0.001)$, and in working dogs it was greater on $\operatorname{diet} \mathrm{B}$ than on $\operatorname{diet} \mathrm{A}(P<0.05)$. When the dogs were tethered the availability of the fat in diets $\mathrm{A}$ and $\mathrm{C}$ was greater than in diet $\mathrm{B}(P<0.00 \mathrm{I})$.

Differences in the availabilities of the food constituents to tethered and to working dogs were tested on a between-dog basis, and were approximate, as no account was taken of the weight-matching of the groups. In working dogs $\mathrm{N}$ availability was greater than in tethered dogs both for $\operatorname{diet} \mathrm{A}(P<0.00 \mathrm{I})$ and for $\operatorname{diet} \mathrm{B}(P<0.0 \mathrm{r})$. There was no evidence of any difference in the availability of fat to tethered and to working dogs fed on either diet.

\section{Performance}

Towards the end of the first field trial one dog, Bodger, who had been fed on diet A, refused his food, became listless and apathetic, and began to vomit continuously. When removed from the trial and fed on seal meat he recovered within $48 \mathrm{~h}$. Such episodes did not occur with dogs eating diets B and C. 


\section{DISCUSSION}

Diets $\mathrm{B}$ and $\mathrm{C}$ were better utilized than $\operatorname{diet} \mathrm{A}$, but $\mathrm{I} \mathrm{lb} /$ day was inadequate to maintain the weight of tethered dogs, and working dogs lost weight rapidly when fed on any of the three diets (Fig. I). Diarrhoea, which was constant in $\operatorname{dogs}$ fed on $\operatorname{diet} \mathrm{A}$, did not occur in dogs fed on diet $\mathrm{B}$ or $\mathrm{C}$.

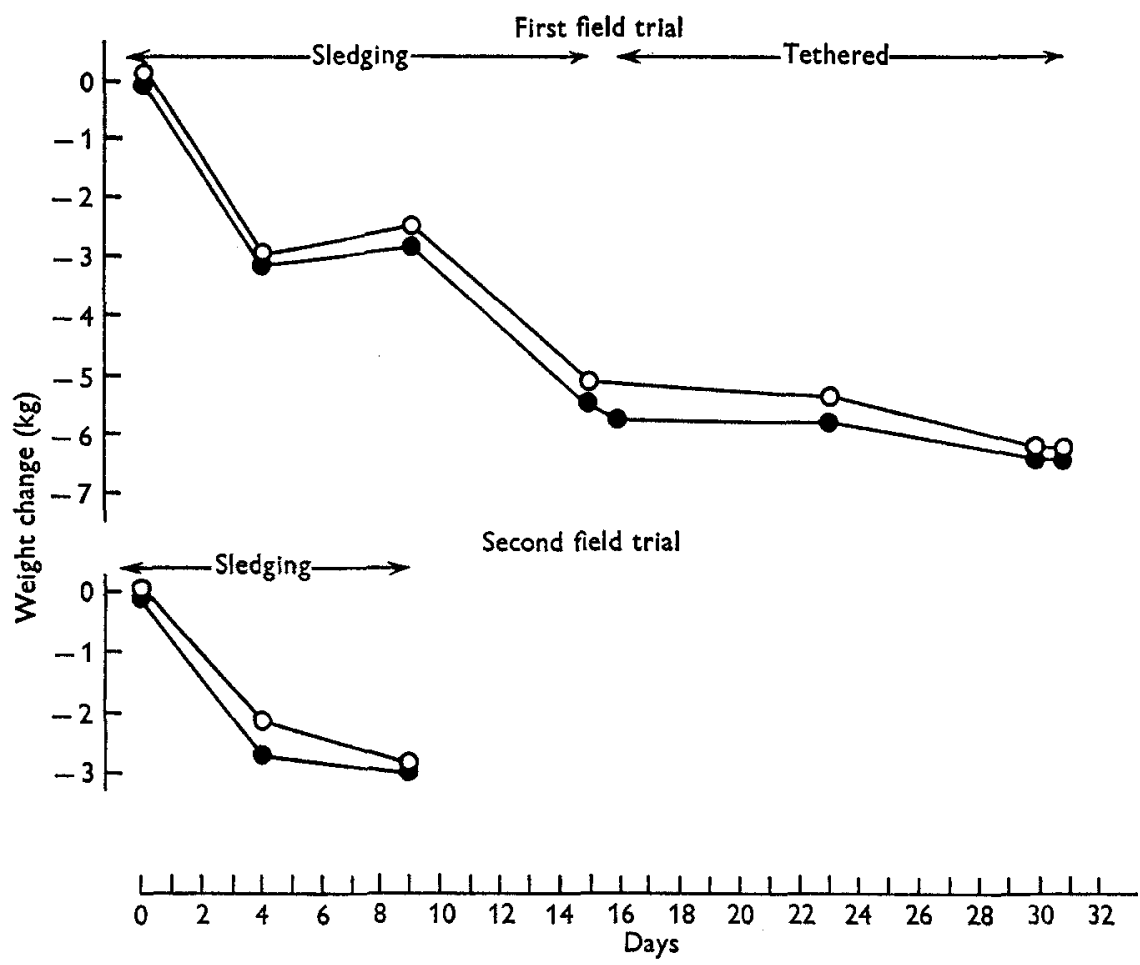

Fig. I. Mean cumulative weight changes (unadjusted) of sledge dogs during the field feeding trials. Two groups of four dogs each were compared. The greater weight loss of working dogs is clearly illustrated. - diet A; $\circ-0$, diet B (see p. 278).

No differences were found in the weight changes of dogs given the old or the new diets. Since the difference in available calories between $\operatorname{diet} \mathrm{A}$ and $\operatorname{diet} \mathrm{B}$ or $\operatorname{diet} \mathrm{C}$ was about $300 \mathrm{kcal} / \mathrm{day}$, differences in weight loss of the order of $40 \mathrm{~g} /$ day might have been expected, but such differences would undoubtedly be obscured by the insensitivity of the weighing technique. Differences in water balance on the three diets may also have masked differences in weight change. Taylor et al. (1959) deduced from experiments in Britain that water retention occurred in dogs given diet A, and water requirements on this diet were possibly large so as to replace water loss in the faeces. On diets $B$ and $C$ faecal loss of water was greatly reduced, but because the protein source was fish meal these diets contained large amounts of inorganic salts. It is therefore likely that water requirements were large on all the diets.

The large loss of $\mathrm{N}$ in the faeces of $\operatorname{dogs}$ fed on $\operatorname{diet} \mathrm{A}$, reported by Taylor et al. 
(1959), was confirmed in these experiments, and the utilization of $\mathrm{N}$ by dogs fed on diets $\mathrm{B}$ and $\mathrm{C}$ was shown to be much better. The high protein intake of dogs fed on

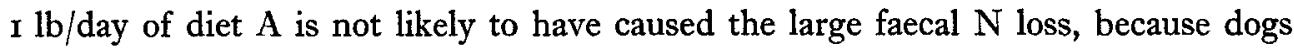
fed on seal meat take almost the same amount of protein and rather more fat, but excrete in the faeces only about $7 \%$ of ingested $\mathrm{N}\left(\mathrm{Orr}, \mathrm{I} \mathrm{I}_{3}\right)$. The dogs receive $2-3 \mathrm{~kg}$ of seal meat and blubber on alternate days; they usually eat all of the meat and some of the blubber, taking more blubber in the winter months and leaving large amounts in the summer. The proportions of meat and blubber vary according to the way in which the meat is cut, and the amounts used in the analyses for Table 2 were arbitrary. Nevertheless, on a seal-meat diet dogs must take up to $250 \mathrm{~g}$ protein each day, a variable amount of fat, and about $2 \mathrm{mg}$ thiamine.

Various heat treatments of protein have been shown to reduce its digestibility (Mendel \& Fine, r912; Morgan \& Kern, I934; Mader, Schroeder \& Smith, I949; Bissett \& Tarr, 1954; Harms \& Scott, 1956; Schroeder, Iacobellis \& Smith, 1961). Since the protein source of diet A was minced beef that had been steamwashed, the processing of the meat meal used may have caused the poor protein utilization.

With all the diets the availability of fat was within the normal range, although it was less with diet B than with either diet A or C. In husky dogs, Taylor et al. (I959) found that faecal fat amounted to $3-7 \%$ of the ingested fat, whereas for men eating a high-fat diet in polar regions Butson (1950) reported that faecal fat was $7 \%$ of the dietary intake, and Masterton, Lewis \& Widdowson (1957) found that it was 3-4\% of the ingested fat during sledging journeys.

Since the availability of $\mathrm{N}$ was greater for working than for tethered dogs, whereas the availability of fat remained within the normal range, it appears that the diet was better utilized during hard work.

Diet $B$ has been used by the Canadian Defence Research Board, by the TransAntarctic Expedition and by the British Antarctic Survey. Although comparison of the performance of dog teams fed on different diets is complicated by the fact that morale and interest or boredom play a large part (Taylor, 1957 a), dog drivers on these expeditions have reported that dogs perform better on diet $\mathrm{B}$ than on diet $\mathrm{A}$.

The figures obtained in the feeding trials can be used to estimate the energy requirements of sledge dogs. The daily calorie equivalents of the foodstuffs available to tethered dogs were (from Table 3): from diet A $2080 \mathrm{kcal}$, from diet B $2360 \mathrm{kcal}$, and from diet $\mathrm{C} 2340 \mathrm{kcal}$. Since the dogs still lost weight it is evident that they required over $2360 \mathrm{kcal} / \mathrm{day}$ to maintain body-weight. It has been calculated that the maximum useful external work which a sledge dog can perform in $\mathrm{I} \mathrm{h}$ is $\mathrm{I} 20 \mathrm{kcal}$ and in a normal day's travel between 250 and $400 \mathrm{kcal}$ (Taylor, $1957 \mathrm{~b}$ ). These figures represent a calorie requirement of 1000-1600 kcal/day if the efficiency of muscular work is taken to be as high as $25 \%$ (Hill, 1939, I950). If it be assumed that the calorie requirements for external work were additional to the requirements of tethered dogs, the total calorie requirement of a working dog probably lies between 3500 and $4600 \mathrm{kcal} / \mathrm{day}$. Large as this requirement seems for an animal of between 35 and $45 \mathrm{~kg}$ body-weight, the weight losses of working dogs seem to support the estimate (Fig. I). 
It is thus improbable that a $\mathrm{I} \mathrm{lb}$ block of concentrated food can be provided that would be nutritionally adequate in all respects, since $\mathrm{I} l \mathrm{lb}$ of fat daily would provide barely sufficient energy for working sledge dogs.

\section{SUMMARY}

I. Thirty-two husky dogs were fed on three different concentrated diets in the Antarctic. Feeding trials, during which each dog was given $\mathrm{I} l \mathrm{lb} /$ day of one or other diet, were performed both during sledging journeys and while the dogs were kept tethered and unworked.

2. When fed on a diet containing $30 \%$ protein, $40 \%$ fat and ro- $20 \%$ carbohydrate the dogs excreted much less nitrogen and tended to lose less weight than on a diet containing approximately $66 \%$ protein and $33 \%$ fat. The large amounts of $\mathrm{N}$ excreted by dogs fed on the diet containing $66 \%$ protein may be related to the source of protein ingredients rather than to the absolute amounts of protein. Fat availability on both diets was within the normal range.

3. The evidence suggests that the energy expenditure of working sledge dogs, weighing $35-45 \mathrm{~kg}$, is of the order of $4000 \mathrm{kcal} / \mathrm{day}$, and may be greater.

I thank Dr E. M. Widdowson for criticism and advice and for arranging for the analyses of the foodstuffs and the faeces, Mrs M. P. Williams for performing the analyses, Dr E. Kodicek for the analyses for thiamine, Miss P. Howlett for statistical advice and Lt-Cdr A. B. Erskine, R.N., and Mr K. Hoskins for invaluable assistance and encouragement under trying conditions in the Antarctic.

\section{REFERENCES}

Association of Official Agricultural Chemists (1950). Official Methods of Analysis, 7th ed. Washington, D.C.: Association of Official Agricultural Chemists.

Bingham, E. W. (I94I). Polar Rec. 3, 367.

Bissett, H. M. \& Tarr, H. L. A. (1954). Poult. Sci. 33, 250.

Butson, A. R. C. (1950). Lancet, 258, 993.

Harms, A. J. \& Scott, P. P. (1956). F. Sci. Fd Agric. 7, 477.

Harris, L. J. \& Wang, V. L. (1941). Biochem. $\mathcal{F} .35$, 1050.

Hill, A. V. (1939). Proc, roy. Soc. B, 127, 434.

Hill, A. V. (1950). Sci. Progr. Twent. Cent. 38, 209.

King, E. J. (1946). Micro-analysis in Medical Biochemistry. London: J. and A. Churchill.

McCance, R. A. \& Shipp, H. L. (1933). Spec. Rep. Ser. med. Res. Coun., Lond., no. 187.

McCance, R. A., Widdowson, E. M. \& Shackleton, L. R. B. (1936). Spec. Rep. Ser. med. Res. Coun., Lond., no. 213.

Mader, I. J., Schroeder, L. J. \& Smith, A. H. (r949). F. Nutr. 39, 34I.

Masterton, J. P., Lewis, H. E. \& Widdowson, E. M. (I957). Brit. $\mathscr{J}$. Nutr. Ir, 346.

Mendel, L. B. \& Fine, M. S. (1912). 7. biol. Chem. 11, 5.

Morgan, A. F. \& Kern, G. E. (1934). F. Nutr. 7, 367 .

Orr, N. W. M. (1963). F. Physiol. 165, 51 $P$.

Schroeder, L. J., Iacobellis, M. \& Smith, A. H. (r96r). F. Nutr. 73, I43.

Taylor, R. J. F. (1957a). Polar Rec. 8, 3 I7.

Taylor, R. J. F. (1957b). F. Physiol. 137, 210.

Taylor, R. J. F., Worden, A. N. \& Waterhouse, C. E. (1959). Brit. F. Nutr. 13, I.

Watkins, H. G. (1932). Geogr. F. 79, 466.

Widdowson, E. M. \& Southgate, D. A. T. (1959). Biochem. F. 72, 200. 